\title{
Assessment of anti-HBs antibody concentration in children with juvenile idiopathic arthritis treated with biological drugs, vaccinated against viral type $B$ hepatitis in infancy
}

\author{
Izabela Szczygielska, Elżbieta Hernik, Agnieszka Gazda, Beata Kołodziejczyk, Piotr Gietka
}

Clinic of Developmental Age Rheumatology, National Institute of Geriatric, Rheumatology and Rehabilitation, Warsaw, Poland

\begin{abstract}
Objectives: The introduction of vaccinations against viral hepatitis B in the years 1994-1996 in Poland significantly improved the epidemiological situation of hepatitis B virus (HBV) infections in our country. According to the report of the National Institute of Public Health - National Institute of Hygiene in 2018, 40 cases of acute hepatitis B were noted while still in the 1980s between 10 and 20 thousand new cases were reported annually. The aim of the study was to determine whether in children treated with biological drugs (adalimumab, etanercept, infliximab) due to juvenile idiopathic arthritis (JIA), vaccinated against hepatitis B in infancy, a protective concentration of anti-HBS antibodies persists. In patients, the value $\geq 10 \mathrm{mIU} / \mathrm{ml}$ is regarded as a protective concentration of antibodies, determined at least four weeks after administration of the last vaccine dose. Among healthy individuals, presence of anti-HBs antibodies in any concentration means seroprotection. No booster vaccinations are recommended in basically vaccinated healthy individuals.

Material and methods: The concentrations of anti-HBs antibodies were determined in 56 children with JIA (38 girls $-67.9 \%$ and 18 boys $-32.1 \%$ ) aged from 2 years and 4 months to 17.5 years, treated for at least three months with biological drugs. The diagnosis of JIA was made based on the International League of Associations for Rheumatology (ILAR) criteria. All studied patients were at the stable stage of the disease and received a full course of hepatitis B vaccination during infancy (in accordance with 0,1,6 months injection scheme).

Results: In the studied children a protective anti-HBs antibody concentration was found in 34 cases (60.7\%), and 22 children (39.3\%) had anti-HBs antibody concentration $<10 \mathrm{mIU} / \mathrm{ml}$ (in these children no seroprotection was found).

Conclusions: The post-vaccination antibody concentration should be determined in children with IIA, treated with biological drugs and, in case of absence of a protective concentration, revaccination should be started.
\end{abstract}

Key words: chronic hepatitis B, biological drugs, anti-HBs antibodies, HBV vaccination.

\section{Introduction}

Viral hepatitis $B$ is a disease caused by hepatitis B virus (HBV), which is a DNA virus belonging to the Hepadnaviridae family, primarily showing an affinity to the hepatocytes. It causes acute, peracute or chronic hepatitis.

Hepatitis B virus is possibly the most infectious pathogen for humans, about 50-100 times more infec- tious than HIV; just $0.0004 \mathrm{ml}$ of blood is sufficient to cause infection [1].

Groups remaining at a high risk of HBV infection include:

- subjects coming into close contact with individuals with acute or chronic hepatitis B,

- patients subjected to invasive diagnostic or therapeutic procedures,

Address of correspondence:

Izabela Szczygielska, Clinic of Developmental Age Rheumatology, National Institute of Geriatric, Rheumatology and Rehabilitation,

1 Spartańska St., 02-637 Warsaw, Poland, e-mail: iza.szczygielska@op.pl

Submitted: 20.11.2019; Accepted: 20.02.2020 
- newborns born to women infected with HBV,

- patients treated with blood-derived preparations,

- patients undergoing haemodialysis,

- individuals having unprotected sex with multiple partners, including homosexual contacts,

- individuals addicted to intravenous shere needles during intravenous drug use,

- patients over the age of 60 and with diabetes,

- subjects traveling to countries with the high incidence of HBV infections,

- medical staff and workers of educational care centres (occupationally coming into contact with blood or other body fluids) [2].

Hepatitis B is a widespread disease encountered worldwide, although its occurrence varies significantly, depending on geographical area. The percentage of individuals with chronic HBV infection ranges from $1 \%$ to even $20 \%$ [3, 4]. The lowest percentage of individuals chronically infected with HBV is found in North America and Western Europe - less than 1\% of the general population [3]. On the other hand, in African countries, in East Asia and Eastern Europe about 5\% to 10\% of the adult population are infected with HBV [3]. Currently it is estimated that 350-400 million people worldwide have chronic hepatitis B, in 2015257 millions of people were reported HBV infection [3, 4]. Annually, due to complications such as hepatocellular carcinoma or liver cirrhosis the patients die, in 2015 hepatitis B resulted in an estimated 887000 deaths [3].

The incidence of hepatitis B in Poland in the 1980s was among the highest in Europe [5]. The register of hepatitis B patients in Poland has been conducted since 1979 [5]. Between 1979 and 1985, from 15276 (1982) to 16763 (1985) new cases of hepatitis B were annually noted in Poland [5]. The incidence over that period ranged from 42 to 45.2 per 100000 population [5].

The epidemiological situation of HBV infections in Poland improved significantly after introduction in the years 1994-1996 of anti-hepatitis B vaccination into the calendar of obligatory vaccinations. Already two years after the introduction of the vaccinations, the incidence of hepatitis $B$ in the group of children aged below three years decreased by half - from 39.8 to 19.9 per 100000 population [6]. Currently, according to the National Institute of Public Health - National Institute of Hygiene (NIPZ-PZH) report, in 2018 in Poland 3195 new cases of all types of hepatitis B (including chronic infections) were reported, the incidence rate was 8.32 per 100000 population. Only 40 cases of acute hepatitis B were noted; the incidence was estimated at 0.1 per 100000 population [7]. Currently, the group of patients with hepatitis $B$ includes mainly elderly people or young adults not included in the vaccination programme in the years 1994-1996.
The effectiveness of the vaccination is assessed as high; it is estimated that it produces immunity in over $95 \%$ of the healthy vaccinated individuals [8]. The post-vaccination immunity is of dual character: humoral - associated with presence of specific neutralising antibodies (anti-HBs), and cellular - associated with $\mathrm{T}$ and $B$ cells. Owing to the $T$ and B memory cells the immunity to HBV infection is maintained in healthy individuals. According to the current guidelines of the Protective Vaccination Programme (PVP), in healthy individuals after a basic vaccination against hepatitis B in the past, no booster vaccinations are recommended [2]. Revaccination after a basic vaccination, if the concentration of anti-HBs antibodies is $<10 \mathrm{mlU} / \mathrm{ml}$, is recommended in chronically ill patients: those infected with hepatitis C virus, patients at an advanced stage of kidney disease with a glomerular filtration rate $<30 \mathrm{ml} / \mathrm{min}$, patients on dialysis, diabetic patients, patients with malignancies during immunosuppressive treatment and after organ transplantation and immunodeficient patients [2].

In patients with malignancies during immunosuppressive treatment and in those after organ transplantation, the seroprotection index should be $\geq 100 \mathrm{mlU} / \mathrm{ml}$. In such patients, monitoring of antibodies is recommended every six months, and in case of absent seroprotection a double dose of the vaccine should be given [2]. In the remaining above-mentioned patients, revaccination is started with one dose of the vaccine and in case of no response the whole vaccination cycle should be continued. Individuals in whom after repeated revaccination no protective concentration of the antibodies is found should be regarded as not responding to the vaccination and, in case of a significant exposure to HBV, post-exposure management should be instituted in them [9].

Patients with juvenile idiopathic arthritis (JIA) certainly belong to the group at increased risk of HBV infections, compared with their healthy peers, in view of the course of the disease itself, disturbed immune response, immunosuppressive treatment with both biological and non-biological disease-modifying drugs (DMARDs), frequent hospitalisations and finally various invasive therapeutic-diagnostic procedures. The question thus arises whether we should determine serum anti-HBs antibody concentration in our patients and whether, in case of absent seroprotection, we should give them subsequent vaccine doses.

The aim of the study is to determine whether a protective serum anti-HBs antibody concentration ( $\geq 10 \mathrm{mlU} / \mathrm{ml}$ ) is maintained in children with JIA receiving biological therapy, previously vaccinated in infancy against hepatitis B.

\section{Material and methods}

The concentration of anti-HBs antibodies was determined in the sera of 56 JIA patients under the care of the 
Department and Outpatient Clinic of the Developmental Age, National Institute of Geriatrics, Rheumatology and Rehabilitation, with JIA treated with biological drugs. Inclusion criteria:

- age 2-18 years,

- documented vaccination against hepatitis B in infancy,

- stable stage of the disease (no growing values of inflammatory markers such as erythrocyte sedimentation rate, $\mathrm{C}$-reactive protein, no malaise, no new pain or joint oedema,

- the CHAQ index maximum 0.5-1,

- documented JIA diagnosis (diagnosis made based on the ILAR criteria) [10],

- biological treatment minimum for three months (adalimumab, etanercept, tocilizumab),

- written parental consent for participation in this study. Exclusion criteria:

- biological treatment less than 3 months,

- lack of documentation of full vaccination course in infancy, against hepatitis B or vaccination according to vaccination regimen other than 0, 1, 6 months,

- children with severe disease and disease exacerbation $\mathrm{CHAQ}>1$,

- not obtaining written parental consent.

\section{Procedure}

All children were vaccinated according to the 0, 1, 6 months schedule with the Engerix- $B$ vaccine (GlaxoSmithKline) or Euvax-B (LG Chem Life Sciences, Poland) or Hepavax-Gene TF (Janssen-Cilag International).

The concentration of anti-HBs antibodies was determined by an immunochemical method on a Vitros ECIQ analyser, Ortho Clinical Diagnostics JסJ.

\section{Statistical methods}

The normality of the distribution of tested parameters was checked using the Shapiro-Wilk test. The comparison of the groups in respect of antibody concentration was conducted using Kruskal-Wallis and Mann-Whitney tests. The comparison of the groups in respect of vaccination effectiveness was conducted using Fisher's exact test. The relationship between the time after the last vaccination and antibody concentration for each group was assessed through calculation of Spearman's rank correlation coefficient $(r)$. All calculations were conducted using R 3.4.1 software.

\section{Ethical standards}

The study was approved by the Bioethical Committee at the National Institute of Geriatric, Rheumatology and Rehabilitation (29 May 2014).

\section{Study participants}

The characteristics of the group are shown in Table I.

In the study group the patients with polyarticular form of JIA dominated. The division of the group depending on the form of JIA is presented in Table II.

In the study group only one child was receiving a biological drug in monotherapy; most children, i.e. 49 (87.5\%), were treated with a biological drug combined with methotrexate (MTX) in a dose $15 \mathrm{mg} / \mathrm{m}^{2}, 5.35 \%$ $(n=3)$ with MTX and prednisone 0.1-0.2 $\mathrm{mg}$ per $\mathrm{kg}$ of

Table I. Study group characteristics

\begin{tabular}{|lc|}
\hline Feature & \multicolumn{1}{c|}{ Value } \\
\hline Girls & $38(67.9 \%)$ \\
\hline Boys & $18(32.1 \%)$ \\
\hline Mean age & 13 years (min 2.4 - max 18 years) \\
\hline $\begin{array}{l}\text { Time after the last } \\
\text { vaccination }\end{array}$ & $\begin{array}{c}\text { Mean } 10 \text { years and } 8 \text { months } \\
\text { (from 2 to 17 years) }\end{array}$ \\
\hline Disease duration & $\begin{array}{c}\text { Mean 7 years and 4 months } \\
\text { (1 year and 4 months }-14 \text { years) }\end{array}$ \\
\hline
\end{tabular}

Table II. Division of the group depending on type of juvenile idiopathic arthritis (JIA)

\begin{tabular}{|lcc|}
\hline Diagnosis & $\begin{array}{c}\text { Number } \\
\text { of } \\
\text { patients }\end{array}$ & Percentage \\
\hline JIA - systemic form (sJIA) & 7 & 12.5 \\
\hline JIA - polyarticular form (pJIA) & 27 & 48.2 \\
\hline With presence of rheumatoid factor & 2 & 3.6 \\
\hline $\begin{array}{l}\text { Without presence of rheumatoid } \\
\text { factor }\end{array}$ & 25 & 44.6 \\
\hline Uveitis & 3 & 5.4 \\
\hline JIA - oligoarticular form (oJIA) & 15 & 26.8 \\
\hline Uveitis & 3 & 5.4 \\
\hline Enthesitis-related arthritis (JIA-ERA) & 5 & 8.9 \\
\hline Psoriatic arthritis (PsA) & 2 & 3.6 \\
\hline
\end{tabular}

Table III. Treatment with biological drugs in studied groups

\begin{tabular}{|lcc|}
\hline $\begin{array}{l}\text { Biological } \\
\text { drug }\end{array}$ & Dose & $n(\%)$ \\
\hline Etanercept & $\begin{array}{c}0.4 \mathrm{mg} / \mathrm{kg} \text { b.w. twice weekly } \\
0.8 \mathrm{mg} / \mathrm{kg} \text { b.w. once weekly }\end{array}$ & $\begin{array}{c}27 \\
(48.2)\end{array}$ \\
\hline $\begin{array}{c}\text { Adalimumab } \\
\text { children with b.w. > 30 kg 40 mg } \\
\text { every 2 weeks }\end{array}$ & $\begin{array}{c}20 \\
(35.71)\end{array}$ \\
\hline $\begin{array}{c}\text { children with b.w. }<30 \mathrm{~kg} 20 \mathrm{mg} \\
\text { every 2 weeks }\end{array}$ & \\
\hline & $\begin{array}{c}\text { 8-12 mg/kg b.w. every 2 or every } \\
4 \text { weeks }\end{array}$ & $9(16.1)$ \\
\hline
\end{tabular}


Table IV. Anti-HBs antibody serum concentration depending on gender

\begin{tabular}{|lcccc|}
\hline Group & $n$ & Median & Q1 & Q3 \\
\hline Girls & 38 & 15.7 & 2.0 & 71.9 \\
\hline Boys & 18 & 80.0 & 9.7 & 182.8 \\
\hline Total & 56 & 22.9 & 2.0 & 111.6 \\
\hline
\end{tabular}

$p=0.07$

Table V. Anti-HBs antibody serum concentration depending on form of juvenile idiopathic arthritis (JIA)

\begin{tabular}{|lcccc|}
\hline Diagnosis & $n$ & Median & Q1 & Q3 \\
\hline JIA-ERA & 5 & 72.5 & 72.1 & 156.8 \\
\hline SIIA & 7 & 58.0 & 24.9 & 238.2 \\
\hline PJIA & 27 & 4.5 & 2.0 & 40.0 \\
\hline oJIA & 15 & 39.8 & 2.0 & 228.4 \\
\hline PsA & 2 & 108.3 & 97.9 & 118.8 \\
\hline Total & 56 & 22.9 & 2.0 & 111.6 \\
\hline
\end{tabular}

JIA-ERA - enthesitis-related arthritis, sJIA - JIA - systemic form, pJIA - JIA - polyarticular form, oJIA - JIA - oligoarticular form, PsA - psoriatic arthritis; $p=0.089$.

body weight, and $5.35 \%(n=3)$ were treated with biological drug with combination with cyclosporine at dose 2-3 mg per kg of body weight. Table III summarizes the treatment of patients.

\section{Results}

In 22 of studied patients, $39.33 \%$ had no protective concentration of anti-HBs antibodies (the concentration was lower than $10 \mathrm{mlU} / \mathrm{ml}$ ) and in the remaining 34 cases (60.7\%) seroprotection was confirmed (anti-HBs antibody concentration $>10 \mathrm{mlU} / \mathrm{ml}$ ). The anti-HBs antibody concentration was higher in the group of boys than girls but that difference was statistically insignificant ( $p$-value for Mann-Whitney test $=0.07$ ) (Table IV).

No statistically significant correlation was observed between the time after the last vaccination and anti-HBs antibody concentration (Spearman's correlation coefficient $=0.054 ; p=0.692$ ).

No statistically significant correlation was also observed between the age of the studied children and the antibody concentration (Spearman's correlation coefficient $r=0.038, p=0.781$ ).

The lowest anti-HBs antibody concentration was detected in children with polyarticular onset of JIA ( $p J \mid A)$, but these results were characterised by a high scatter and that relationship was not statistically significant (Table V).

\section{Discussion}

The introduction in the 1990s of vaccinations against hepatitis B changed the epidemiological situation of acute hepatitis B not only in Poland but also in other countries participating in that vaccination programme. Individuals with chronic HBV infection still pose, however, a great problem, since they are a reservoir of the virus. As was shown in the report of the European Centre for Disease Prevention and Control (ECDC), in the European Union (EU), since 2008 a constant growth tendency has been observed in respect of the reported cases of chronic hepatitis B (cHBV) [11]. The incidence of cHBV increased from 6.7 per 100000 population in 2008 to 10.2 per 100000 population in 2017 [11]. The greatest incidence was noted in the age between 25 and 34 years. The predominant infection route in the case of $\mathrm{cHBV}$ was vertical transmission (41\%), followed by infections acquired during various medical procedures (28\%). Poland is one of the foremost EU countries in which most cHBV cases acquired during medical procedures are reported [11].

In the present study $39.3 \%$ of children with JIA did not have sufficient post-vaccination seroprotection, which draws attention to the problem and the risk of infection in this population.

In 2015 we published a study determining anti-HBs antibody concentration in the sera of 50 patients with autoimmune inflammatory rheumatic diseases (AIRD) receiving immunosupressive treatment [12]. The control group consisted of 50 healthy children. We demonstrated that among patients treated with immunosupressants in $50 \%$ cases $(n=25)$ no seroprotection was found, while in the control group only in $4 \%(n=2)$ no seroprotection was present [12].

Maritsi et al. [13] obtained similar results, and among 89 children with various forms of JIA treated with 
immunosuppressants, a protective anti-HBs concentration was found in $55 \%$ of patients, while in the control group of healthy children the percentage was up to $92 \%$ $(n=89)$. Maritsi's work and our research indicated that among children with JIA almost half do not have protective levels of anti-HBs antibodies.

Those children were in the group at increased risk of HBV infection. Certainly, therefore, they should be given booster vaccine doses. According to the recommendations of the European League Against Rheumatism (EULAR) expert group, vaccination against HBV is indicated in patients from the risk groups, i.e. travelling to endemic regions, individuals coming into close contact with HBV-infected persons or medical staff $[14,15]$.

The passive (in the form of specific anti-HBs immunoglobulin - HIBIG) or active (in the form of booster vaccine) prevention is recommended for unvaccinated individuals or patients with insufficient concentration of anti-HBV antibodies in the case of exposure to HBV [14]

According to the EULAR recommendations in children with rheumatic diseases, vaccinations against hepatitis B, tetanus, diphtheria, pertussis, Haemophilus influenzae B ( $\mathrm{HiB})$, pneumococci, and meningococci are recommended following the national PVP $[14,15]$. During immunosuppressive treatment, the concentrations of specific post-vaccination antibodies reach values regarded as protective, although they are lower than in patients without immunosuppression [14, 15].

As suggested by the literature data, vaccinations against hepatitis B in children with JIA are safe, and are characterised by high immunogenicity in children treated both with biological and non-biological DMARDs [16, 17].

Kasapcopur et al. [16] demonstrated effectiveness of vaccination against HBV. Among 39 children with JIA (various forms of the disease) treated with methotrexate (MTX) or MTX and prednisone, almost all studied patients had seroprotection, i.e. 38 out of 39 (98\%). No undesirable post-vaccination effects or disease exacerbation were observed [16].

Also Nerome et al. [17] demonstrated the safety and immunogenicity of hepatitis B vaccination. In the studied group of $18 \mathrm{JIA}$ patients treated with biological drugs (etanercept, adalimumab, tocilizumab, infliximab), 72\% $(n=13)$ of patients confirmed protective serum levels of anti-hepatitis B antibodies. These children were not previously vaccinated against hepatitis $B$, and they were vaccinated during the above-mentioned treatment, according to the 0, 1, 6 months schedule with the Engerix-B vaccine. Adverse symptoms were observed in 5 patients and were comparable to those seen in healthy children. No JIA exacerbation was observed in this group [17].

According to the EULAR guidelines, inactivated vaccines are safe for patients with AlIRDs, irrespective of the basic therapy, while live attenuated vaccines should be considered with caution individually $[14,15]$. Currently the new EULAR guidelines show greater flexibility in the attitude towards some live vaccines. As suggested in the literature, vaccinations against varicella, zoster, measles, mumps and rubella (MMR - the second booster dose) can be safe for patients with JIA, treated with both biological and non-biological DMARDs [18-20].

Further studies are, however, needed. According to the EULAR guidelines an individual approach to every patient is recommended. In vaccination planning, all factors affecting the risk of infection and the safety of the vaccination itself should always be taken into account. Some vaccinations should preferably be performed before the planned biological treatment. However, we should always remember not to delay the underlying treatment because of a vaccination [14].

Focusing on the present topic it is worth noting that in the adult group of AlIRD patients there were not sufficient data on the efficacy of hepatitis $B$ vaccination, but there is agreement that the serum level of antibodies correlates with protection [14]. Also in adult AIIRD patient populations some studies revealed an insufficient response to HBV vaccination, which was considered as associated with biological treatment [21]. In the case of a weak or non-response to vaccination, a high dose may be considered, but this has not been proven to increase the response to vaccination [14].

It seems therefore highly justified to monitor the antibody concentration in patients with rheumatic diseases, both before planned institution of treatment with both biological and non-biological DMARDs and before planned surgical operations.

In Poland the determinations of anti-HBs antibody concentrations in chronically ill patients, as part of medical qualification for vaccination, are free of charge [22].

\section{Conclusions}

Vaccination against hepatitis $B$ is safe, irrespective of the type of therapy in JIA patients.

There is a risk of a lack of response to the recommended hepatitis $B$ vaccination at the classic dose and vaccination schedule as demonstrated by the present study.

Anti-vaccine antibody serum levels in JIA patients should be evaluated and a booster dose of vaccine should be considered in individual situations.

In justified cases, passive prevention in the form of $\mathrm{HIBIG}$, or passive-active prevention (vaccination and HIBIG) may be considered.

The authors declare no conflict of interest. 


\section{References}

1. Komiya $\mathrm{Y}$, Katayama $\mathrm{K}$, Yugi $\mathrm{H}$, et al. Minimum infectious dose of hepatitis B virus in chimpanzees and difference in the dynamics of viremia between genotype $A$ and genotype $C$. Transfusion 2008; 48: 286-294, DOI: 10.1111/j.15372995.2007.01522.x.

2. Kuchar E, Mrukowicz J, Stryczyńska-Kozubal J, et al. Szczepienia przeciwko wirusowemu zapaleniu wątroby typu B. Szczepienia 2017; 4: 88-91.

3. World Health Organization Newletter. Hepatitis B Key facts. Lipiec, 2015. http://www.who.int/mediacentre/factsheets/ fs204/en/ (access: 19.11.2019).

4. Kowalska M, Kalinowski P, Bojakowska U, Krauze M. Epidemiology of hepatitis B in Poland in 2010-2014. J Education, Health and Sport. 2017; 7: 414-426, DOI: 10.5281/zenodo.344961.

5. Magdzik W, Czarkowski M. Sytuacja epidemiologiczna wirusowego zapalenia wątroby typu B w Polsce w latach 1979-2004. [Epidemiological situation of hepatitis B in Poland in the years 1979-2004]. Prz Epidemiol 2006; 60: 471-480.

6. Woynarowski M. Polski dziecięcy program interferonowy leczenia przewlekłego zapalenia wątroby typu B. Koncepcja, realizacja i efekty. Rozprawa habilitacyjna, Warszawa 2005.

7. Informacje o zachorowaniach na choroby zakaźne i zatruciach w Polsce w 2018 roku. NIPZ-PZH Warszawa, 2019. http:// wwwold.pzh.gov.pl/oldpage/epimeld/2018/INF_18_12B.pdf (access: 19.11.2019)

8. Pokorska-Lis M, Marczyńska M. Czy nastolatki szczepione w wieku niemowlęcym mają odporność przeciwko WZW typu B? Prz Lek 2010; 67: 13-17.

9. Kuchar E, Załęski A, Kozłowska-Jałowska A. Profilaktyka poekspozycyjna chorób zakaźnych. Szczepienia 2018; 2: 76-81.

10. Petty RE, Southwood TR, Manners P, et al. International League of Association for Rheumatology Classification of Juvenile Idiopathic Arthritis: second revision, Edmonton, 2001. J Rheumatol 2004; 31: 390-392.

11.Stępień M. Rośnie liczba przewlekłych przypadków WZW B wkrajach UE/EEA. https://szczepienia.pzh.gov.pl/rosnie-liczba-zglaszanych-przewleklych-przypadkow-wzwb-w-rajach-eu-eea/ (access: 19.11.2019)

12. Szczygielska I, Hernik E, Kwiatkowska M, et al. Ocena stężenia poszczepiennych przeciwciał anty-HBs $u$ dzieci z zapalnymi układowymi chorobami tkanki łącznej leczonych immunosupresyjnie. [Assessment of the level of vaccine-induced anti-HBs antibodies in children with inflammatory systemic connective tissue diseases treated with immunosuppression]. Reumatologia 2015; 53: 56-60, DOI: 10.5114/reum.2015.51503.

13. Maritsi D, Vartzelis G, Soldatou A, et al. Markedly decreased antibody titers against hepatitis $B$ in previously immunised children presenting with juvenile idiopathic arthritis. Clin Exp Rheumatol 2013; 31: 969-973.

14. Furer V, Rondaan Ch, Hejistek MW, et al. 2019 update of EULAR recommendations for vaccination in adult patients with autoimmune inflammatory rheumatic diseases. Ann Rheum Dis 2020; 79: 39-52, DOI: 10.1136/annrheumdis-2019-215882.

15. Heijstek MW, Ott de Briun LM, Bijl M, et al. EULAR recommendations for vaccination in peadiatric with rheumatic diseases. Ann Rheum Dis 2011; 70: 1704-1712, DOI: 10.1136/ ard.2011.150193

16. Kasapçopur Ö, Çullu F, Kamburoðlu-Goksel A, et al. Hepatitis B vaccination in children with juvenile idiopathic arthritis. Ann Rheum Dis 2004; 63: 1128-1130.

17. Nerome Y, Akaike H, Nonaka Y, et al. The safety and effectiveness of HBV vaccination in patients with juvenile idiopathic arthritis controlled by treatment. Mod Rheumatol 2016; 26: 368-371, DOI: 10.3109/14397595.2015.1085608.

18. Toplak N, Avčin T. Long-term safety and efficacy of varicella vaccination in children with juvenile idiopathic arthritis treated with biologic therapy. Vaccine 2015; 33: 4056-4059, DOI: 10.1016/j.vaccine.2015.06.086

19. Groot N, Pileggi G, Sandoval CB, et al. Varicella vaccination elicits a humoral and cellular response in children with rheumatic diseases using immune suppressive treatment. Vaccine 2017; 35: 2818-2822, DOI: 10.1016/j.vaccine.2017

20. Silva CA, Terreri MT, Aikawa NE, et al. Vaccination practice in children with rheumatic disease. Rev Bras Reumatol 2010; 50: 351-361.

21. Haykir Solay A, Eser F. High dose hepatitis B vaccine is not effective in patients using immunomodulatory drugs: a pilot study. Hum Vaccin Immunother 2019; 15: 1177-1182, DOI: 10.1080/21645515.2019.1574151.

22. Rywczak I, Ściubisz M. Program szczepień ochronnych w Polsce na 2019 rok. Szczepienia 2019; 1: 37-49. 